\title{
Secretome characterization of the lignocellulose-degrading fungi Pycnoporus sanguineus and Ganoderma applanatum
}

\author{
Albertina Gauna $^{\mathrm{a}}$, Alvaro S. Larran ${ }^{\mathrm{a}, \mathrm{b}}$, Susana R. Feldman ${ }^{\mathrm{a}, \mathrm{b}, \mathrm{c}}$, Hugo R. Permingeat ${ }^{\mathrm{a}, \mathrm{b}}$, \\ Valeria E. Perotti ${ }^{\mathrm{a}, *}$ \\ ${ }^{a}$ Facultad de Ciencias Agrarias, Universidad Nacional de Rosario, Campo \\ Experimental Villarino, S2125ZAA Zavalla, Santa Fe, Argentina \\ ${ }^{b}$ Instituto de Investigaciones en Ciencias Agrarias de Rosario (IICAR-CONICET), \\ Campo Experimental Villarino, S2125ZAA Zavalla, Santa Fe, Argentina \\ ${ }^{c}$ Consejo de Investigaciones Universidad Nacional de Rosario, Maipú 1165, 2000 \\ Rosario, Santa Fe, Argentina
}

* Corresponding author. Tel.: +54 3414970080 (ext 1261)

E-mail address: valeria.perotti@unr.edu.ar 


\begin{abstract}
$\mathrm{C} 4$ grasses are common species in rangelands around the world and represent an attractive option for second-generation biofuels production. Although they display a high polysaccharide content and reach great levels of biomass accumulation, there is a major technical issue to be solved before they can be considered as biofuels feedstock: lignin removal. Concerning this, Pycnoporus and Ganoderma fungal genera have been highlighted due to their ability to hydrolyze lignocellulose. The goals here were to evaluate the pretreatment efficiency using $P$. sanguineus and G. applanatum secretomes harvested from a glucose-free inductive medium and to identify the fungal enzymatic activities responsible for the lignin degradation and glucose release. The findings show that $P$. sanguineus secretome exhibits a higher activity of lignocellulolytic enzymes compared to the one from G. applanatum. Interestingly, zymograms in presence of glucose suggest that a $\beta$-glucosidase isoform from $P$. sanguineus could be glucosetolerant. The proteomic approach carried out allowed to identify 73 and 180 different proteins for $G$. applanatum and $P$. sanguineus secretomes, respectively, which were functionally classified in five main categories, and a miscellaneous group. Many uncharacterized proteins were found in both secretomes, reflecting that greater research is still needed for a better comprehension of lignocellulose degradation.
\end{abstract}

Keywords: lignin-degrading enzymes, lignocellulosic biomass, proteomics, rangeland species, white rot fungi 


\section{Introduction}

Energy demand has grown exponentially since the Industrial Revolution, with the collateral effect of increasing $\mathrm{CO}_{2}$ and other greenhouse gases levels in the atmosphere. Intergovernmental Panel on Climate Change (IPCC 2014) claims these gases are responsible for global climate change. Therefore, during the last decade, there has been a rising interest in renewable energy sources, especially in second generation biofuels, which do not compete with food supplies. In this context, different rangeland C4 grasses have been proposed as potential sources of fermentable sugars (Limayem and Ricke, 2012; Alfenore and Molina-Jouve, 2016).

Panicum prionitis Ness (=Coleataenia prionitis (Ness) Soreng), a dominant C4 grass species in plant communities of the floodplain and islands of the Paraná River (Argentina), represents an attractive option for bioethanol production. $P$. prionitis can reach high levels of biomass accumulation (22.35 Mg of dry matter per hectare; Sosa et al. 2019) and displays a high polysaccharide composition (around 70\% of dry weight, as reported in Gauna et al., 2018). However, there is a major technical issue to be addressed before it can be used for bioethanol industrial production: lignin removal. Briefly, lignocellulosic biomass can be converted into ethanol in four steps: pretreatment, enzymatic hydrolysis, fermentation, and distillation of ethanol produced (Salehi Jouzani and Taherzadeh, 2015; Robak and Balcerek, 2018). During pretreatment, lignin within cell wall (about $7 \%$ in P. prionitis) must be removed to allow the access of hydrolytic enzymes to cellulose and hemicellulose. This procedure is usually the bottleneck for economically viable second-generation biofuel production (Mood et al., 2013; Masran et al., 2016; Cheah et al., 2020). 
Few microorganisms are capable of hydrolyzing lignocellulose. Among them, basidiomycetes causing white rot wood decay are particularly effective because they use lignocellulose of plant cell walls as a carbon source during secondary metabolism triggered by nutrient starvation (Chandel et al., 2015). These microorganisms synthesize and secrete a considerable number of hydrolytic enzymes, including cellulases, hemicellulases, lignin-modifying enzymes, and other accessory enzymes (Manavalan et al., 2015) which can be employed in a wide range of industrial processes (Camarero et al., 2002; Georis et al., 2003; Polizeli et al., 2005).

Some species of Pycnoporus and Ganoderma genera have been highlighted due to their ability to synthesize valuable molecules including antioxidants, antibiotics, antiinflammatory, and anti-tumoral compounds, as well as to efficiently produce laccases, xylanases, and other industrial interesting enzymes (Smânia et al., 2003; Zhou et al., 2012; Yu et al., 2015). White rot basidiomycetes from Pycnoporus spp. are widely studied for their ability to: (i) secrete thermostable laccases (Eugenio et al., 2009; Lu et al., 2010; Uzan et al., 2010) and endoxylanases (Niderhaus et al., 2018) as part of their ligninolytic system, (ii) produce efficient cellulolytic and hemicellulolytic extracts (Scarpa et al., 2019), and (iii) produce $\alpha$-amilases (Siqueira et al., 1997).

Current advances in MS-based proteomics provide powerful tools for studies that involve complex biological systems, even more after the increasing number of genomes from filamentous fungi that have become recently available (Guo et al., 2018; Shankar et al., 2019; Jain et al., 2020).

In previous works, the group has assessed the potential of $P$. sanguineus and $G$. applanatum secretomes (extracellular proteome) to act as efficient biological pretreatment agents in lignin degradation and glucose release, using green and senescent 
biomass of Spartina argentinensis Parodi (=Sporobolus spartinus (Trin.) P.M. Peterson and Saarela) (Larran et al., 2015) and P. prionitis (Gauna et al., 2018). The goals here were to evaluate the pretreatment efficiency using secretomes harvested from an inductive medium (using $P$. prionitis leaves as a carbon source) and to identify the fungal enzymatic activities responsible for such lignin degradation and glucose release. A proteomic approach was carried out to promote a deep characterization of the secretomes from these filamentous fungi. 


\section{Materials and methods}

\subsection{Biomass, chemicals and enzymes}

P. prionitis plants were originally collected in the flooding valley of the Parana River in Argentina $\left(32^{\circ} 52^{\prime} 43.04^{\prime \prime} \mathrm{S} ; 60^{\circ} 35^{\prime} 0.33^{\prime \prime} \mathrm{W}\right)$ and were treated as described in Gauna et al. (2018). Chemicals and enzymes used were purchased from Sigma-Aldrich Argentina unless stated otherwise.

\subsection{Fungal species}

Two white rot fungi were assessed: $P$. sanguineus and $G$. applanatum. Fungal basidiocarps were collected as described in Gauna et al. (2018), and stock cultures were maintained on Potato Glucose Agar (PGA) at $4^{\circ} \mathrm{C}$ in the dark.

For inoculation with fungal spores, a $3 \mathrm{~mm}^{3}$ plug was transferred to the center of a PGAcontaining Petri plate and grown at $28{ }^{\circ} \mathrm{C}$ for 7 days. Fungal spores were obtained by washing Petri dishes with $10 \mathrm{~mL}$ of $8 \mathrm{~g} / \mathrm{L}$ sodium chloride supplemented with $40 \mu \mathrm{L}$ of Tween 20, and then filtering the supernatant through a sterile paper filter to remove the mycelia. Spores were quantified using a Neubaüer counting chamber and were maintained in $20 \%$ glycerol at $-80{ }^{\circ} \mathrm{C}$.

\subsection{Pretreatments with fungal secretomes}

A $3 \mathrm{~mm}^{3}$ piece from the peripheral region of each fungus actively growing on PGA plates was inoculated into flasks containing $20 \mathrm{~mL}$ of $50 \mathrm{mM}$ sterile sodium acetate buffer $\mathrm{pH}$ 6 with $P$. prionitis ground leaves (50-50\% senescent-green) at $7.5 \%(\mathrm{w} / \mathrm{v})$ (Inductive Medium, IM). Flasks were incubated at $28{ }^{\circ} \mathrm{C}$ with rotary shaking $(120 \mathrm{rpm})$ for 7 days. Secretomes were filtered under sterile conditions and used as pretreatment agents.

Erlenmeyer flasks containing $50 \mathrm{mg}$ of ground dried green or senescent leaves of $P$. prionitis were incubated at $37^{\circ} \mathrm{C}$ for $48 \mathrm{~h}$, after the addition of $0.5 \mathrm{~mL}$ of fungal secretome 
diluted in $4.5 \mathrm{~mL}$ of $50 \mathrm{mM}$ sodium acetate buffer $\mathrm{pH}$ 4. Pretreatments were performed over three biological replicates of $P$. prionitis biomass and were followed by a hydrolysis step. Blanks and controls were prepared as detailed in Gauna et al. (2018). After the whole process, a $20 \mu \mathrm{L}$ aliquot was taken for glucose determination using an enzymatic glycemia kit (Wiener Lab, Rosario, Argentina).

Hydrolyzed cellulose and the contribution of each step to the total glucose released were calculated as described previously (Larran et al., 2015).

\subsection{Plate assays and zymogram analysis}

P. sanguineus and G. applanatum were grown in two conditions: IM described in the section 2.3 and Wheat Bran (WB) medium, using this alternative carbon source at $7.5 \%$ (w/v) in $50 \mathrm{mM}$ sodium acetate buffer $\mathrm{pH}$ 6. A suspension of $1.10^{6}$ spores was used to inoculate $100 \mathrm{~mL}$ of both media in $500 \mathrm{~mL}$ baffled flasks. After 7 days, secretomes were used to assay cellulase, xylanase, manganese peroxidase $(\mathrm{MnP})$, and laccase activities in Petri dishes. Negative controls were prepared by boiling the fungal secretomes for 5 minutes.

Protein concentration from each secretome was estimated using the Bio-Rad protein assay reagent (Bio-Rad, Hercules, CA, USA) and bovine serum albumin as standard. Twenty $\mu \mathrm{g}$ of total secreted proteins were added into different wells within each plate and incubated overnight at $30{ }^{\circ} \mathrm{C}$.

For cellulase and xylanase activities, plates containing $1.8 \%$ agar and $0.5 \%$ carboxymethyl cellulose (CMC) or $0.5 \%$ of xylan as substrate were prepared, respectively. These plates were subsequently stained for 20 min with $0.1 \%$ congo red under slight shaking and subsequently detained, first with $1 \mathrm{M} \mathrm{NaCl}$ for 20 min and then 
with $0.5 \%$ acetic acid, which was immediately rinsed off with cold water. Hydrolytic zones were observed against a red background.

MnP activity was determined in plates containing $1.8 \%$ agar, $20 \mathrm{mM}$ 2,6dimethoxyphenol (DMP), $5 \mathrm{mM} \mathrm{MnSO}_{4}$, and $10 \mathrm{mM} \mathrm{H}_{2} \mathrm{O}_{2}$ as substrates after the incubation at $30^{\circ} \mathrm{C}$. Laccase activity was determined similarly, but plates contained $1.8 \%$ agar and $1 \mathrm{mM}$ guayacol as substrate. Oxidative dark brown zones were observed against the clear background as an indicator of laccase and peroxidase activity.

The secreted proteins were subjected to a native-PAGE (native, 10\% acrylamide) for the detection of $\beta$-glucosidase activity. Electrophoresis was run at $12 \mathrm{~mA}$ and at $4{ }^{\circ} \mathrm{C}$ until the front dye left the gel. After running, the gel was soaked in $0.2 \mathrm{M}$ sodium acetate buffer $\mathrm{pH} 5$ for $10 \mathrm{~min}$ at room temperature. The gel was then incubated in $0.2 \mathrm{M}$ sodium acetate buffer containing $0.1 \%(\mathrm{w} / \mathrm{v})$ esculin and $0.03 \%(\mathrm{w} / \mathrm{v})$ ferric chloride for $5 \mathrm{~min}$ at $50{ }^{\circ} \mathrm{C}$. Alternatively, gels were incubated 10 min with sodium acetate buffer $(0.2 \mathrm{M}, \mathrm{pH} 5)$ in the presence of either 1 or $2 \mathrm{M}$ glucose, and then were revealed with the esculin solution keeping the same glucose concentration. Each reactive band was quantified by densitometric analysis using ImageJ software.

\subsection{Secreted proteins extraction for proteomic analysis}

Protein extraction was carried out according to Medina et al. (2004) with minor modifications. An inoculum of $1.10^{6}$ spores of P. sanguineus or G. applanatum was added to $20 \mathrm{~mL}$ of $\mathrm{IM}$ and incubated at $28^{\circ} \mathrm{C}$ with rotary shaking (200 rpm) for 4 weeks. After this incubation period, the semi-solid medium obtained was extracted adding $5 \mathrm{~mL}$ of 50 $\mathrm{mM}$ sodium acetate buffer $\mathrm{pH} 4$ containing $1 \mathrm{mM}$ phenylmethylsulfonyl fluoride (PMSF) for $1 \mathrm{~h}$ at $4{ }^{\circ} \mathrm{C}$ under slight shaking. The secretome was recovered by filtration through filter paper and proteins were precipitated with $1 \mathrm{~V}$ of $20 \%$ trichloroacetic acid (TCA) 
and incubated at $-20^{\circ} \mathrm{C} \mathrm{ON}$. Subsequently, tubes were centrifuged at maximum speed for 10 minutes at $4{ }^{\circ} \mathrm{C}$, washed three times with $70 \%$ ethanol, and finally with acetone, discarding the supernatant in each step. The pellet was dried at room temperature. Precipitated proteins were resuspended in $100 \mu \mathrm{L}$ of $50 \mathrm{mM}$ sodium acetate buffer $\mathrm{pH} 6$ and were subjected to three sonication pulses of 5 seconds and $20 \%$ amplitude. Tubes were centrifuged at maximum speed and the supernatant was used for the next steps. First, a $20 \mu \mathrm{g}$ aliquot of each sample was incubated for $45 \mathrm{~min}$ with $10 \mathrm{mM}$ of DTT at $56{ }^{\circ} \mathrm{C}$ and then, with $20 \mathrm{mM}$ of iodoacetamide at room temperature in darkness. Samples were sent to CEBIQUIEM (Facultad de Ciencias Exactas y Naturales, Universidad de Buenos Aires, Argentina) for further analysis.

\subsection{LC-MS and data search analysis}

The proteins were treated with trypsin and then cleaned with Zip-Tip C18 to extract the salts; the digested peptides were lyophilized by Speed Vac, and finally resuspended in $0.1 \%$ formic acid solution for mass spectrometric analysis. All solvents and reagents used were of LC-MS quality. The first peptide separation was carried out in a reverse phase capillary column $(75 \mu \mathrm{m} \times 150 \mathrm{~mm})$ packed with $\mathrm{C} 18(2,6 \mu \mathrm{m}, 150 \AA$, Thermo Scientific $)$. The flow rate was maintained at $300 \mathrm{~nL} / \mathrm{min}$. Mobile phase $\mathrm{A}(0.1 \%$ formic acid in water $)$ and mobile phase B ( $0.1 \%$ formic acid in acetonitrile) were used to establish the $120 \mathrm{~min}$ gradient comprising 110 min of 5-35\% B, 1 min 35-95\% B, and 9 min of 95\% B followed by re-equilibrating at $5 \% \mathrm{~B}$ for $5 \mathrm{~min}$. The peptides were then analyzed by electrospray ionization (Easy-Spray, Thermo Scientific) with $3.5 \mathrm{kV}$ potential. The peptides were separated in a second dimension by Mass Spectrometry (MS) (Q-Exactive, Thermo Scientific) with a High Collision Dissociation cell (HCD) and an Orbitrap analyzer. The equipment configuration allowed peptide identification simultaneously with 
chromatography resolution, obtaining Full MS and MS/MS. The spectra obtained were analyzed with "Proteome Discoverer" and database search was carried out in Uniprot (http://www.uniprot.org/) for P. sanguineus and against the functional annotation database of G. lucidum genome for G. applanatum (Chen et al., 2012). The precursor mass and MS/MS tolerances were $10 \mathrm{ppm}$ and $0.05 \mathrm{Da}$, respectively. All the peptides were identified with a high confidence level. Two missed cleavage sites of trypsin were allowed. The oxidation $(\mathrm{M})$ and carbamidomethylation $(\mathrm{C})$ were set as variable and fixed modifications, respectively. The presence of a secretion signal peptide was determined with SignalP.

\subsection{Statistical analysis}

Data used for graphs of glucose released came from experiments repeated in triplicate and were analyzed using Sigma-Plot and GraphPad software. Inferential statistics was carried out applying a Two-way ANOVA test with a significance level $<0.1$, to identify data with statistically significant differences. 


\section{Results and discussion}

\subsection{The Inductive Medium triggers a greater pretreatment efficiency using $P$. sanguineus secretome}

Fungal secretomes from G. applanatum and P. sanguineus had previously been tested as biological pretreatment agents, resulting in considerable cellulose degradation levels in Argentinian rangeland species (Larran et al., 2015; Gauna et al., 2018). However, the fungal secretomes from those studies had been obtained in a culture medium with glucose as a carbon source - Potato Glucose (PG) medium-, which is known to transcriptionally repress cellulases, hemicellulases, and other lignocellulolytic enzymes in filamentous fungi (Suzuki et al., 2008; Glass et al., 2013). Moreover, according to previous studies, the absence of glucose and the presence of a lignocellulosic substrate may induce the expression of lignocellulolytic enzymes (Suzuki et al., 2008; Rohr et al., 2013).

In this work, it has been developed and tested an inductive medium (IM) with P. prionitis leaves as a lignocellulosic substrate, which notoriously increased glucose release levels in comparison with PG medium. The results show that glucose release levels depend on the fungal secretome and the biomass used, reaching the highest values with $P$. sanguineus secretome acting on green leaves (Fig. 1). The greater amount of lignin in senescent leaves could hinder accessibility to polysaccharides, causing decay in glucose release. Differences in glucose released between fungal secretomes could be due to the higher protein concentration in P. sanguineus secretome (see section 3.4), although some differential enzymatic activities could also affect the total process, as discussed next. 


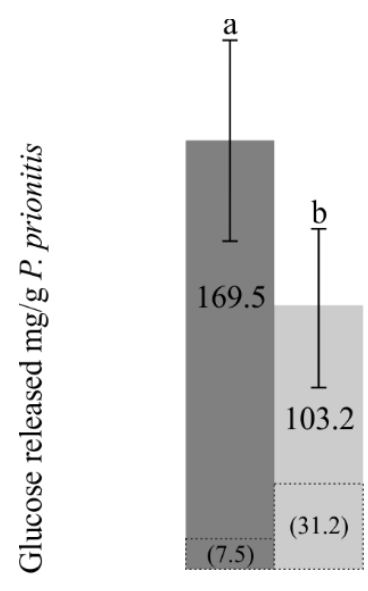

P. sanguineus

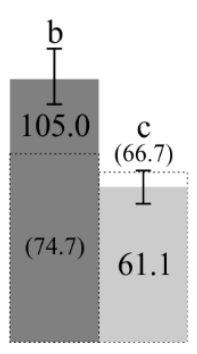

G. applanatum
- Green biomass

Senescent biomass

Figure 1. Total glucose released with fungal secretomes obtained in IM. Numbers in brackets indicate the total glucose released with fungal secretomes obtained in PG medium (Gauna et al., 2018). Error bars represent the standard error. Different letters indicate statistically significant differences.

The use of $P$. sanguineus secretome obtained in IM allowed a 22.5-fold and a 3-fold increase in glucose release compared to the secretome produced in PG medium over green and senescent biomass, respectively (Gauna et al., 2018) (Fig. 1). Regarding G. applanatum secretome, the increase in glucose released respect to PG medium was only 1.4-fold for green biomass and no significant changes were observed for senescent biomass. Differences in the total glucose released between the two culture media, PG vs IM, may be explained by the catabolic repression process as well as the inducible lignocellulolytic enzymes, as described above.

The comparison between the percent of hydrolyzed cellulose in IM vs. PG medium allows an easier appreciation of the differential behavior of each fungus (Table 1). The contribution of $P$. sanguineus secretome to the pretreatment step was notoriously higher than the G. applanatum secretome contribution, similarly to the behavior observed in previous studies (Gauna et al., 2018). The higher contribution of $P$. sanguineus secretome to the pretreatment process could be due to an increased production/activity of lignin 
degrading enzymes; whereas in the case of G. applanatum, the higher contribution to the hydrolysis step could be due to a proportionally greater cellulolytic activity. The IM tested in this work triggers an increase in the pretreatment contribution of $P$. sanguineus secretome respect to PG medium (up to 80 and $85 \%$ vs. 34 and $59 \%$ in green and senescent biomass, respectively). This shows that $P$. sanguineus enzyme consortium involved in lignin degradation is preferentially inducible by the presence of a lignocellulosic substrate and the absence of glucose. In contrast, no differences in pretreatment contribution were observed with G. applanatum secretome between both media.

Table 1. Contribution of pretreatment and hydrolysis steps to glucose release on green and senescent $P$. prionitis biomass. The numbers in brackets correspond to the values obtained in PG medium previously (Gauna et al., 2018).

\begin{tabular}{|c|c|c|c|c|}
\hline & \multicolumn{2}{|c|}{ P. sanguineus } & \multicolumn{2}{|c|}{ G. applanatum } \\
\hline & $\begin{array}{c}\text { Green } \\
\text { biomass }\end{array}$ & $\begin{array}{c}\text { Senescent } \\
\text { biomass }\end{array}$ & $\begin{array}{c}\text { Green } \\
\text { biomass }\end{array}$ & $\begin{array}{c}\text { Senescent } \\
\text { biomass }\end{array}$ \\
\hline $\begin{array}{l}\% \text { Total glucose released } \\
\text { corresponding to pretreatment }\end{array}$ & $80.0^{(34)}$ & $84.7^{(59)}$ & $36.1^{(31)}$ & $13.9^{(16)}$ \\
\hline $\begin{array}{l}\% \text { Total glucose released } \\
\text { corresponding to hydrolysis }\end{array}$ & $20.0^{(66)}$ & $15.3^{(41)}$ & $63.9^{(69)}$ & $86.1^{(84)}$ \\
\hline$\%$ Total hydrolyzed cellulose & $46.1^{(2)}$ & $26.6^{(7.9)}$ & $28.1^{(20.3)}$ & $15.5^{(16.9)}$ \\
\hline
\end{tabular}

\subsection{The activity of lignocellulolytic enzymes is higher in $P$. sanguineus secretome}

The activity of the main lignocellulolytic enzymes identified in the secretomes was assessed in Petri dishes. The employment of wheat bran (WB) as a carbon source was previously evaluated and proved to substantially contribute to the expression of lignocellulolytic enzymes (Scarpa et al., 2019). Therefore, WB was used as a control to evaluate the different activities from IM. Figure 2 shows the plate assays for cellulase, 
xylanase, laccase, and MnP activities. Only the cellulase activity was observed in both secretomes with both carbon sources, with the greatest activity corresponding to $P$. sanguineus secretome. Curiously, xylanase activity was detected in both secretomes from fungi growing in IM, while a very low activity was observed in WB only in P. sanguineus secretome. Laccase and MnP activities were only detected in P. sanguineus secretome with both carbon sources, being greater in WB medium.

The exclusive detection of MnP and laccase activities in $P$. sanguineus secretome could provide a rational explanation for its greater contribution to the pretreatment process compared to G. applanatum secretome, as stated in section 3.1. In compliance with the lower percentage of hydrolyzed cellulose, G. applanatum showed a reduced activity of all the enzymes assayed regarding $P$. sanguineus.

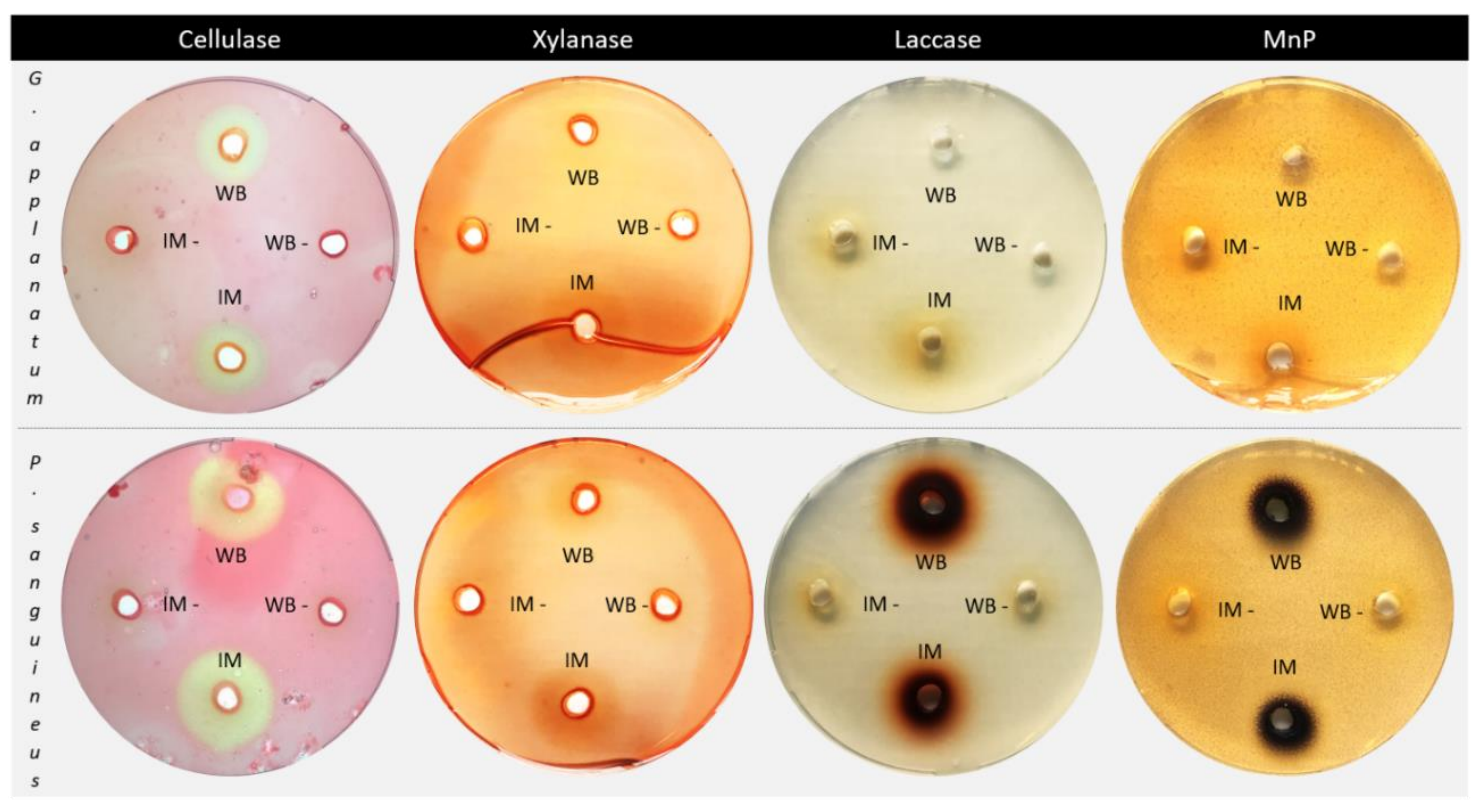

Figure 2. Plate assays of lignocellulosic activities. WB and IM: different culture media and their negative controls (WB-, IM-). Twenty $\mu$ g of total secreted proteins were added into different wells within each plate.

\section{3 $P$. sanguineus secretes a putatively glucose-tolerant $\beta$-glucosidase}


$\beta$-glucosidases play a critical role among the enzymes involved in plant biomass deconstruction, since they catalyze the last step of sugar degradation before the fermentation phase (Santos et al., 2019), mitigating product inhibition of cellulases and hemicellulases. However, most fungal $\beta$-glucosidases characterized show a weak activity at high glucose concentrations, limiting their enzymatic hydrolysis capacity in industrial processes (Xiao et al., 2004). Besides, fungi do not generally secrete large quantities of $\beta$-glucosidases into the extracellular medium (Cairns and Esen, 2010; Jeya et al., 2010). Hence, numerous studies have focused on the differential characteristics (including sequence and structural data) that would lead to glucose tolerance, in order to find better natural producers and/or improve the engineering strategies of these enzymes (de Giuseppe et al., 2014; Guo et al., 2016; Mariano et al., 2017; Salgado et al., 2018; Santos et al., 2019).

To investigate the presence of any glucose-tolerant $\beta$-glucosidase isoform, it has been performed zymograms for this activity under different glucose concentrations. As shown in Figure 3, the highest $\beta$-glucosidase activity was achieved with WB as a carbon source on $P$. sanguineus secretome, like laccase and $\mathrm{MnP}$ activities (see section 3.2). This secretome shows two isoforms, the high molecular weight (HMW) isoform presented the highest $\beta$-glucosidase activity in almost all the conditions. The exception was WB medium at glucose $2 \mathrm{M}$, where the contribution of each isoform was equivalent $(50 \%$, lane 11 from Fig. 3A).

The residual activity of each isoform at increasing glucose concentrations showed that the HMW isoform is notoriously affected by this metabolite $(2-5 \%$ residual activity at glucose $2 \mathrm{M}$ ). In contrast, the low molecular weight (LMW) isoform showed a less steep decrease in both tested media (Fig. 3B), suggesting to be a glucose-tolerant $\beta$-glucosidase. 


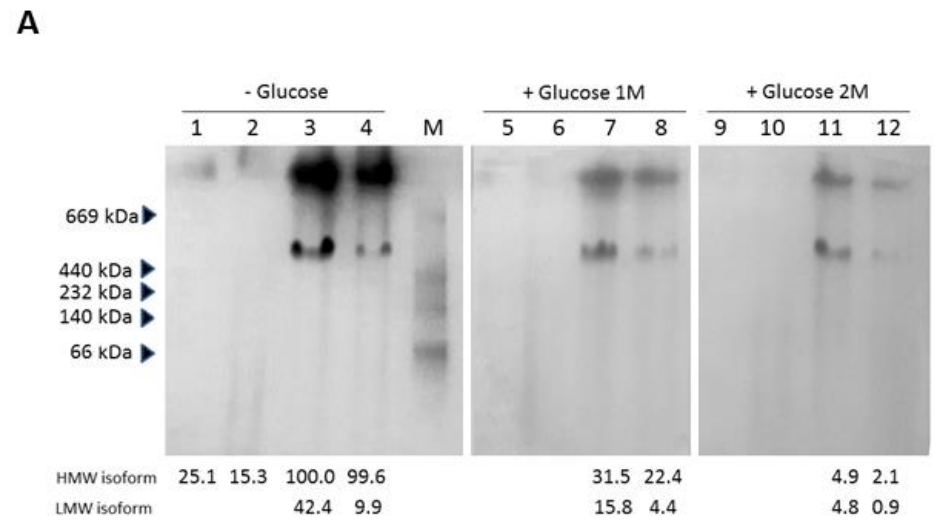

B

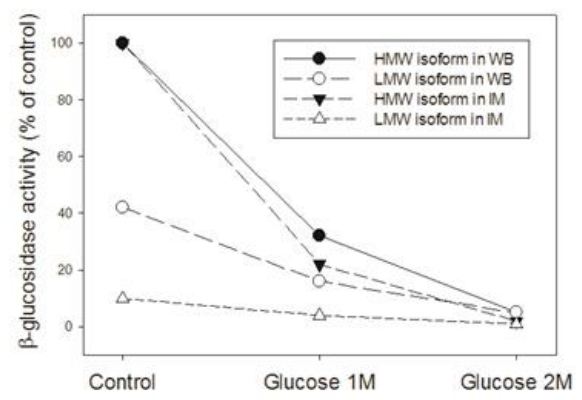

Figure 3. A) Non-denaturing polyacrylamide gel electrophoresis stained by $\beta$-glucosidase activity in absence/presence of glucose. Twenty $\mu \mathrm{g}$ of total secreted proteins were added into different lanes. G. applanatum secretomes were evaluated in lanes 1, 2, 5, 6, 9, and 10; while $P$. sanguineus secretomes were evaluated in lanes $3,4,7,8,11$, and 12 . Odd number lanes were loaded with secretomes from WB medium; while even number lanes contained secretomes from IM. Quantitative zymogram analysis for each isoform relative to HMW isoform from lane 3 is shown at the bottom. M: molecular weight markers B) Decreasing $\beta$-glucosidase activity from each isoform at increasing glucose concentrations.

This finding opens new avenues for second-generation biofuel production regarding the usual limitations of product inhibition for cellulases and hemicellulases. Curiously, this isoform identified as a GH3 family member by MALDI-TOF analysis (Table S1), showed a $10 \%$ residual activity at very high glucose concentrations (2M). Although most glucosetolerant $\beta$-glucosidases characterized belong to the GH1 family (Mariano et al., 2017; Salgado et al., 2018), several exceptions in which they are classified as GH3 family members were reported (Huang et al., 2014; Valappil et al., 2019; Monteiro et al., 2020). 
Moreover, in agreement with the presented results, a recent report has characterized a secreted $\beta$-glucosidase from Aspergillus unguis, identified as a GH3 that resulted in a LMW isoform with intact activity even at $0.5 \mathrm{M}$ glucose. Also, docking analysis supported its high glucose tolerance (Valappil et al., 2019). However, future studies are necessary to assess the significance of these findings.

On the other hand, G. applanatum only exhibited the HMW $\beta$-glucosidase isoform, which showed notoriously lower activity levels than those of $P$. sanguineus. This result could be related either to a lower amount of secreted protein and/or a lower specific activity. In any case, the low basal activity made it impossible to detect this isoform in the presence of glucose.

\subsection{Proteomic characterization reveals many functional biomass-degrading enzymes and uncharacterized proteins in both fungal secretomes}

LC-MS analysis allowed the identification of 180 proteins ranging from 12.2 to 234.3 $\mathrm{kDa}$ and 73 proteins from 13.6 to $223.8 \mathrm{kDa}$ in $P$. sanguineus and $G$. applanatum secretomes, respectively. Calculated $\mathrm{pI}$ varied from 4 to 8 . In both cases, proteins were obtained from IM, and protein concentration in $P$. sanguineus secretome resulted threefold higher than in $G$. applanatum secretome $\left(1.07 \mathrm{mg} \cdot \mathrm{mL}^{-1}\right.$ vs. $0.31 \mathrm{mg} \cdot \mathrm{mL}^{-1}$, respectively). Interestingly, a simulated $2 \mathrm{D}$ gel presentation of each secretome from the LC-MS data fitted the 2D gels obtained experimentally (Fig. S1), validating the coverage of the method used.

The proteomic approach, carried out for the first time in $P$. sanguineus and $G$. applanatum, allowed a deep characterization of the secretomes from these filamentous fungi. Proteins identified in each secretome and their corresponding peptide sequences are fully listed in supplementary tables $\mathrm{S} 2$ and $\mathrm{S} 3$. The majority presented a signal 
peptide. Proteins identified were functionally classified according to their biological role. Figure 4 depicts the functional classification of $P$. sanguineus and $G$. applanatum secreted proteins, which were grouped into cellulose, hemicellulose or lignin-degrading enzymes, glycoside hydrolases, uncharacterized proteins, and others (miscellaneous). It is worth remarking the significant proportion of uncharacterized proteins found in both species. Tables 2 and 3 summarize the characterized proteins from $P$. sanguineus and $G$. applanatum secretomes, respectively.

\section{Ganoderma applanatum}

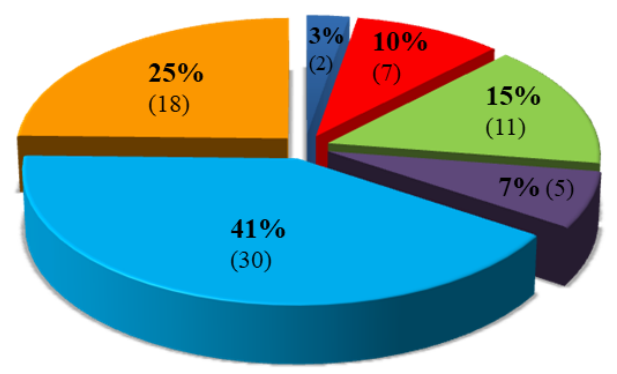

Cellulolytic enzymes

- Hemicellulolytic enzymes

a Lignin-degrading enzymes $\square$ Others

\section{Pycnoporus sanguineus}

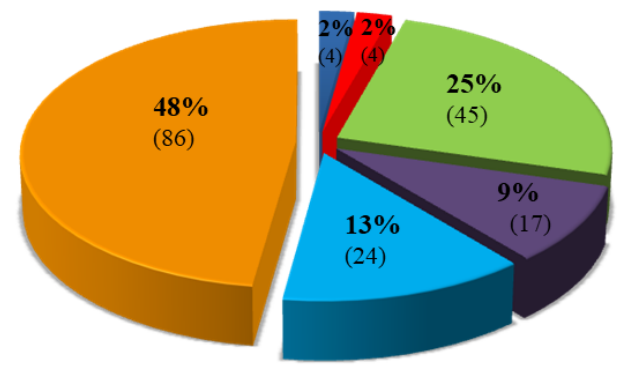

$\square$ Glycoside hydrolases

$\square$ Uncharacterized proteins

Figure 4. Functional classification of the secreted proteins according to their biological role. The numbers in brackets correspond to the number of proteins identified in each group.

Glycoside hydrolases $(\mathrm{GH})$ are a widespread group of enzymes that catalyze the hydrolysis of O- or S-glycosides. They can be classified according to different criteria: sequence or structure-based methods (most used), the stereochemical outcome of the hydrolysis reaction, and exo or endo acting (Cantarel et al., 2009). Given the broad substrate specificity of these enzymes, they can act in several metabolic pathways, such as cellulose, hemicellulose, and lignin degradation. Coherently, they represented a meaningful category in both secretomes (15-25\% of total proteins). 
Cellulases include three major groups of enzymes: endo-glucanases, exo-glucanases (or cellobiohydrolases), and $\beta$-glucosidases, all involved in the conversion of cellulose into glucose (Behera et al., 2017). As was discussed previously, in wood-degrading basidiomycetes, cellulases expression is regulated by carbon catabolite repression mechanisms and by the presence of lignocellulosic substrates (Rohr et al., 2013). Two enzymes from this family (an endo-1,6- $\beta$-glycosidase and a cellobiohydrolase) were found in the secretome of $G$. applanatum, while four (three glucanases and a $\beta$ glycosidase) were identified in the $P$. sanguineus secretome.

Complete hydrolysis of hemicellulose requires of several enzymes: endo-1,4- $\beta$ xylanases, $\quad$ exo-1,4- $\beta$-xylanases, $\quad \beta$-xylosidases, $\quad \beta$-arabynofuranosidases, $\quad \beta$-dgucorinidases, acetylxylanoesterases, galactosidases, mannanases, mannosidases, polysaccharide lyases, phytases, among others (Couturier and Berrin, 2013). Similarly to cellulases, hemicellulases require the presence of a lignocellulosic compound to be transcriptionally induced. At least seven proteins were linked to hemicellulose hydrolysis in the G. applanatum secretome. It has been found three $\beta$-galactosidases, two $\beta$ xylosidases, an $\alpha$-galactosidase, and an $\alpha$-glucosidase. On the other hand, two xylanases, a $\beta$-1,2-mannosidase, and a polysaccharide lyase were detected in the $P$. sanguineus secretome. In brief, at least 10 and $2 \%$ of the different proteins identified in $G$. applanatum and $P$. sanguineus secretomes, respectively, belong to the hemicellulosedegrading enzymes category. However, these percentages are actually higher because the GH identified in both secretomes would be mainly involved in this process, as shown by the most represented families (GH3, GH18, GH55, GH92) (http://www.cazy.org, Jul 2020). 
Several enzymes are involved in lignin breakdown, such as laccases, peroxidases, glycose oxidases, isoamyl-alcohol-oxidases, glutathione reductases, and glutathione-Stransferases. Lacasse, lignin peroxidase, and MnP are considered the most powerful lignin-degrading enzymes (Dashtban et al., 2010). In this study, it has been identified three laccases, a copper radical oxidase, and a non-characterized oxidoreductase in $G$. applanatum secretome. Regarding $P$. sanguineus secretome, five laccases, two cellobiose dehydrogenases, three peroxidases, three glycose-methanol-coline (GMC) oxidoreductases, and four copper radical oxidases were found.

The steps involved in hydrogen peroxide production are particularly important for lignin degradation because this substrate is needed for the catalytic activity of peroxidases. GMC oxidoreductases and copper radical oxidases are involved in such production. Interestingly, a non-characterized GMC oxidoreductase in G. applanatum secretome, as well as a glucose oxidase, an aryl-alcohol-oxidase, and a pyranose oxidase were identified in P. sanguineus secretome. As already mentioned, four copper radical oxidases were also found in $P$. sanguineus secretome, while two of them were glyoxal oxidases. The cellobiose dehydrogenase $(\mathrm{CDH})$ detected in $P$. sanguineus secretome is an extracellular redox enzyme that plays a major role in lignin degradation by breaking beta-ethers, demethoxylating aromatic structures in lignin, and introducing hydroxyl groups in nonphenolic lignin. Moreover, $\mathrm{CDH}$ generates hydroxyls by reducing $\mathrm{Fe}^{3+}$ to $\mathrm{Fe}^{2+}$ and $\mathrm{O}_{2}$ to $\mathrm{H}_{2} \mathrm{O}_{2}$ and may be converted into a quinone-oxidoreductase by proteolysis (Moukha et al., 1999; Manavalan et al., 2012).

Consistently, some proteases were identified (peptidases, endopeptidases, and carboxypeptidases), which were previously associated with lignocellulose degradation 
(Dosoretz et al., 1990) by activating cellulases and cleaving functional domains of the

CDH (Habu et al., 1993; Manavalan et al., 2012).

In addition to all these enzymes, many uncharacterized proteins with unknown function were found in both species, especially in P. sanguineus secretome (48\% of the total). The substantial percentage of uncharacterized proteins indicates the low degree of knowledge of these species, reflecting that a greater amount and depth of experimental work in the subject is needed for a better comprehension and application of the mechanisms underlying lignocellulosic biomass degradation.

Table 2. Detailed information of 94 characterized proteins from $P$. sanguineus secretome. ${ }^{\text {a }}$ matched protein ID was derived from the Uniprot database. ${ }^{b}$ the sequences of matched peptides are shown in Table S2. ${ }^{*}$ indicates the presence of a signal peptide in the matched protein

\begin{tabular}{|c|c|c|c|c|c|c|c|}
\hline Protein name & Ortolog organism & Protein ID ID $^{\mathrm{a}}$ & Score & $\begin{array}{c}\text { Total } \mathbf{n}^{\circ} \\
\text { of } \\
\text { peptides } \\
\text { matches }\end{array}$ & MW & pI & $\begin{array}{l}\text { Functional } \\
\text { classification }\end{array}$ \\
\hline Glucanase * & Pycnoporus cinnabarinus & A0A060SFM6 & 201.02 & 67 & 49.3 & 5.24 & Cellulolytic enzymes \\
\hline Laccase (Fragment) & Trametes sanguinea & D2CSE6 & 149.62 & 36 & 43.1 & 5.62 & Lignin-degrading enzymes \\
\hline Laccase * & Trametes sanguinea & D7F485 & 148.36 & 36 & 56.1 & 5.19 & Lignin-degrading enzymes \\
\hline Glucanase * & Pycnoporus cinnabarinus & A0A060SHA3 & 114.85 & 31 & 47.7 & 5.11 & Cellulolytic enzymes \\
\hline Laccase * & Trametes sanguinea & V5IVB8 & 104.36 & 30 & 56.2 & 6.18 & Lignin-degrading enzymes \\
\hline $\begin{array}{l}\text { Glycoside Hydrolase } \\
\text { Family } 92 \text { protein }\end{array}$ & Pycnoporus cinnabarinus & A0A060STK0 & 81.26 & 24 & 79.1 & 4.88 & Glycoside hydrolases \\
\hline $\begin{array}{l}\text { Glyoxal oxidase (copper } \\
\text { radical oxidases) * }\end{array}$ & Pycnoporus cinnabarinus & A0A060SS83 & 69.97 & 26 & 64.2 & 6.25 & Lignin-degrading enzymes \\
\hline $\begin{array}{l}\text { Glycoside Hidrolase Family } \\
74 *\end{array}$ & Pycnoporus cinnabarinus & A0A060SCW9 & 48.48 & 17 & 88.1 & 5.00 & Glycoside hydrolases \\
\hline Beta-xylanase * & Pycnoporus cinnabarinus & A0A060SAN9 & 46.68 & 14 & 37.7 & 7.74 & Hemicellulolytic enzymes \\
\hline Glucanase * & Pycnoporus cinnabarinus & A0A060ST00 & 42.86 & 16 & 49.1 & 4.65 & Cellulolytic enzymes \\
\hline $\begin{array}{l}\text { Glycoside Hidrolase Family } \\
35 \text { protein }\end{array}$ & Pycnoporus cinnabarinus & A0A060SCS4 & 35.63 & 14 & 114.2 & 5.71 & Glycoside hydrolases \\
\hline $\begin{array}{l}\text { Glycoside Hydrolase } \\
\text { Family } 55 \text { protein* }\end{array}$ & Pycnoporus cinnabarinus & A0A060SJ71 & 34.52 & 11 & 91.8 & 6.27 & Glycoside hydrolases \\
\hline Cellobiose dehydrogenase * & Trametes sanguinea & S5RVR8 & 33.70 & 11 & 81.9 & 5.05 & Lignin-degrading enzymes \\
\hline $\begin{array}{l}\text { Glycoside Hydrolase } \\
\text { Family } 5 \text { protein * }\end{array}$ & Pycnoporus cinnabarinus & A0A060STH0 & 33.17 & 10 & 44.1 & 4.51 & Glycoside hydrolases \\
\hline $\begin{array}{l}\text { Glycoside Hydrolase } \\
\text { Family } 3 \text { protein }\end{array}$ & Pycnoporus cinnabarinus & A0A060SQD5 & 31.72 & 11 & 78.8 & 5.17 & Glycoside hydrolases \\
\hline $\begin{array}{l}\text { Glycoside Hydrolase } \\
\text { Family } 31 \text { protein * }\end{array}$ & Pycnoporus cinnabarinus & A0A060SCJ9 & 30.64 & 9 & 98.4 & 6.07 & Glycoside hydrolases \\
\hline alpha-1,2-Mannosidase * & Pycnoporus cinnabarinus & A0A060S7Y0 & 30.52 & 11 & 58.2 & 5.15 & Hemicellulolytic enzymes \\
\hline $\begin{array}{l}\text { Auxilliary Activities Family } \\
9 \text { protein * }\end{array}$ & Pycnoporus cinnabarinus & A0A060SA61 & 28.84 & 9 & 24.0 & 6.52 & Others \\
\hline $\begin{array}{l}\text { Glycoside Hydrolase } \\
\text { Family } 2 \text { protein * }\end{array}$ & Pycnoporus cinnabarinus & A0A060SVH8 & 28.03 & 7 & 105.1 & 4.68 & Glycoside hydrolases \\
\hline $\begin{array}{l}\text { Glycoside Hydrolase } \\
\text { Family } 5 *\end{array}$ & Pycnoporus cinnabarinus & A0A060SAS1 & 27.14 & 8 & 117.8 & 6.05 & Glycoside hydrolases \\
\hline
\end{tabular}


bioRxiv preprint doi: https://doi.org/10.1101/2020.09.22.308908; this version posted September 23, 2020. The copyright holder for this preprint (which was not certified by peer review) is the author/funder, who has granted bioRxiv a license to display the preprint in perpetuity. It is made available under aCC-BY-NC-ND 4.0 International license.

\begin{tabular}{|l} 
Glycoside Hydrolase \\
Family 3 protein \\
Laccase (Fragment) \\
Glycoside Hydrolase \\
Family 31 protein * \\
Laccase (Fragment) \\
Glyoxal oxidase (copper \\
radical oxidases)* \\
Alpha-amylase * \\
Peptide hydrolase * \\
Glycoside Hydrolase \\
Family 115 protein* \\
Copper radical oxidase * \\
Beta-xylanase* \\
Peroxidase * \\
Glycoside Hydrolase \\
Family 131 protein \\
Glycoside Hydrolase \\
Family 5 protein * \\
Iron reductase domain / \\
Cellobiose dehydrogenase * \\
Tyrosinase \\
Carbohydrate-Binding
\end{tabular}

\section{Module Family 1 protein *}

Glycoside Hydrolase

Family 79 protein *

Glycoside Hydrolase

Family 55 protein *

Glycoside Hydrolase

Family 92 protein

Glycoside Hydrolase

Family 3 protein

Glycoside Hydrolase

Family 18 *

Glycoside Hydrolase

Family 55 protein

Glycoside Hydrolase

Family 76 protein

Pyranose oxidase (GMC

oxidoreductase)

Carboxypeptidase *

Peroxidase (Fragment)

Glycoside Hydrolase

Family 43 protein *

Glycoside Hydrolase

Family 92 protein

Auxilliary Activities

Family 9 / Carbohydrate-

Binding Module Family 1

protein*

Carbohydrate Esterase

Family 16 protein *

Glycoside Hydrolase

Family 12 protein *

Glycoside Hydrolase

Family 3 protein *

Glycoside Hydrolase

Family 20 protein *

Carbohydrate Esterase

Family 15 protein *

Glycoside Hydrolase

Family 18 protein *

Auxilliary Activities

Family 9 protein *

Glycoside Hydrolase

Family 125 protein *

\begin{tabular}{|c|c|c|c|c|c|c|}
\hline Pycnoporus cinnabarinus & A0A060SDX7 & 24.26 & 8 & 69.6 & 4.97 & Glycoside hydrolases \\
\hline Trametes punicea & D2D3A8 & 22.05 & 7 & 43.1 & 5.49 & Lignin-degrading enzymes \\
\hline Pycnoporus cinnabarinus & A0A060SK35 & 21.94 & 7 & 103.9 & 5.64 & Glycoside hydrolases \\
\hline Trametes sanguinea & Q7Z8Q1 & 21.47 & 7 & 31.1 & 6.46 & Lignin-degrading enzymes \\
\hline Pycnoporus cinnabarinus & A0A060SXH6 & 19.79 & 8 & 59.6 & 5.50 & Lignin-degrading enzymes \\
\hline Pycnoporus cinnabarinus & A0A060S3R1 & 18.38 & 6 & 67.4 & 4.88 & Others \\
\hline Pycnoporus cinnabarinus & A0A060SRQ0 & 18.18 & 6 & 52.0 & 5.33 & Others \\
\hline Pycnoporus cinnabarinus & A0A060S8Z6 & 18.10 & 7 & 73.1 & 5.88 & Glycoside hydrolases \\
\hline Pycnoporus cinnabarinus & A0A060SCQ2 & 17.81 & 5 & 106.4 & 4.48 & Lignin-degrading enzymes \\
\hline Pycnoporus cinnabarinus & A0A060SIX2 & 17.39 & 6 & 32.1 & 4.92 & Hemicellulolytic enzymes \\
\hline Pycnoporus cinnabarinus & A0A060S827 & 16.85 & 7 & 38.7 & 4.83 & Lignin-degrading enzymes \\
\hline Pycnoporus cinnabarinus & A0A060SSA3 & 15.96 & 5 & 30.2 & 4.82 & Glycoside hydrolases \\
\hline Pycnoporus cinnabarinus & A0A060SUU9 & 15.02 & 5 & 40.6 & 5.05 & Glycoside hydrolases \\
\hline Pycnoporus cinnabarinus & A0A060SLR9 & 14.45 & 7 & 144.8 & 6.30 & Lignin-degrading enzymes \\
\hline Trametes sanguinea & Q2TL94 & 13.87 & 4 & 68.0 & 5.85 & Others \\
\hline Pycnoporus cinnabarinus & A0A060T0J0 & 13.41 & 5 & 76.7 & 8.28 & Others \\
\hline Pycnoporus cinnabarinus & A0A060S548 & 13.23 & 5 & 42.0 & 7.24 & Glycoside hydrolases \\
\hline Pycnoporus cinnabarinus & A0A060S956 & 13.22 & 3 & 23.1 & 6.24 & Glycoside hydrolases \\
\hline Pycnoporus cinnabarinus & A0A060S5J2 & 12.97 & 5 & 78.2 & 5.40 & Glycoside hydrolases \\
\hline Pycnoporus cinnabarinus & A0A060SAZ4 & 12.03 & 5 & 82.0 & 5.00 & Glycoside hydrolases \\
\hline Pycnoporus cinnabarinus & A0A060S9U7 & 11.32 & 4 & 57.6 & 5.14 & Glycoside hydrolases \\
\hline Pycnoporus cinnabarinus & A0A060S3D6 & 11.26 & 4 & 22.3 & 5.83 & Glycoside hydrolases \\
\hline Pycnoporus cinnabarinus & A0A060SSP9 & 11.25 & 3 & 18.9 & 4.91 & Glycoside hydrolases \\
\hline Pycnoporus cinnabarinus & A0A060S1Q5 & 11.20 & 5 & 79.2 & 8.75 & Lignin-degrading enzymes \\
\hline Pycnoporus cinnabarinus & A0A060SZQ9 & 10.51 & 4 & 52.8 & 5.06 & Others \\
\hline Pycnoporus cinnabarinus & $\mathrm{E} 1 \mathrm{~A} 4 \mathrm{C} 3$ & 10.12 & 5 & 21.4 & 4.51 & Lignin-degrading enzymes \\
\hline Pycnoporus cinnabarinus & A0A060S604 & 10.09 & 3 & 18.9 & 4.46 & Glycoside hydrolases \\
\hline Pycnoporus cinnabarinus & A0A060SYU5 & 10.01 & 4 & 73.5 & 5.40 & Glycoside hydrolases \\
\hline Pycnoporus cinnabarinus & A0A060SH23 & 9.64 & 3 & 33.7 & 5.31 & Others \\
\hline Pycnoporus cinnabarinus & A0A060SP82 & 9.07 & 3 & 37.0 & 4.75 & Others \\
\hline Pycnoporus cinnabarinus & A0A060S792 & 7.76 & 3 & 27.0 & 5.08 & Glycoside hydrolases \\
\hline Pycnoporus cinnabarinus & A0A060SLF1 & 7.73 & 3 & 81.6 & 5.52 & Glycoside hydrolases \\
\hline Pycnoporus cinnabarinus & A0A060SCG5 & 7.57 & 3 & 45.6 & 5.43 & Glycoside hydrolases \\
\hline Pycnoporus cinnabarinus & A0A060S7B6 & 7.51 & 3 & 45.8 & 5.69 & Others \\
\hline Pycnoporus cinnabarinus & A0A060SAA4 & 7.40 & 3 & 47.0 & 4.35 & Glycoside hydrolases \\
\hline Pycnoporus cinnabarinus & A0A060SQW9 & 7.29 & 2 & 26.7 & 7.02 & Others \\
\hline Pycnoporus cinnabarinus & A0A060SHS2 & 6.91 & 2 & 51.8 & 6.18 & Glycoside hydrolases \\
\hline
\end{tabular}


bioRxiv preprint doi: https://doi.org/10.1101/2020.09.22.308908; this version posted September 23, 2020. The copyright holder for this preprint (which was not certified by peer review) is the author/funder, who has granted bioRxiv a license to display the preprint in perpetuity. It is made available under aCC-BY-NC-ND 4.0 International license.

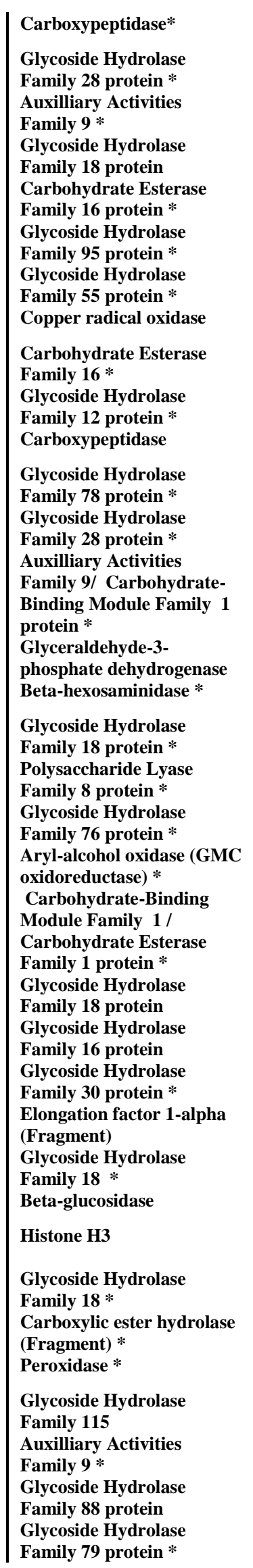

\begin{tabular}{|c|c|c|c|c|c|c|}
\hline Pycnoporus cinnabarinus & A0A060SBL7 & 6.69 & 3 & 71.3 & 5.53 & Others \\
\hline Pycnoporus cinnabarinus & A0A060S2S5 & 6.66 & 2 & 39.3 & 5.31 & Glycoside hydrolases \\
\hline Pycnoporus cinnabarinus & A0A060SB47 & 6.56 & 3 & 101.0 & 7.65 & Others \\
\hline Pycnoporus cinnabarinus & A0A060SXD3 & 6.30 & 2 & 60.9 & 6.47 & Glycoside hydrolases \\
\hline Pycnoporus cinnabarinus & A0A060SSJ5 & 6.20 & 2 & 40.1 & 5.92 & Others \\
\hline Pycnoporus cinnabarinus & A0A060SQK1 & 6.10 & 2 & 73.8 & 5.02 & Glycoside hydrolases \\
\hline Pycnoporus cinnabarinus & A0A060SEI1 & 6.05 & 2 & 80.6 & 5.02 & Glycoside hydrolases \\
\hline Pycnoporus cinnabarinus & A0A060S4G5 & 5.52 & 2 & 78.0 & 5.30 & Lignin-degrading enzymes \\
\hline Pycnoporus cinnabarinus & A0A060S724 & 5.27 & 2 & 34.7 & 5.54 & Others \\
\hline Pycnoporus cinnabarinus & A0A060SCR0 & 5.18 & 2 & 28.1 & 4.96 & Glycoside hydrolases \\
\hline Pycnoporus cinnabarinus & A0A060SQD4 & 4.68 & 2 & 43.8 & 5.30 & Others \\
\hline Pycnoporus cinnabarinus & A0A060SE18 & 4.48 & 1 & 72.1 & 5.57 & Glycoside hydrolases \\
\hline Pycnoporus cinnabarinus & A0A060SP89 & 4.26 & 2 & 45.8 & 6.39 & Glycoside hydrolases \\
\hline Pycnoporus cinnabarinus & A0A060SY86 & 4.10 & 1 & 33.0 & 4.74 & Others \\
\hline Pycnoporus coccineus & Q5TLD0 & 3.44 & 1 & 36.3 & 7.44 & Others \\
\hline Pycnoporus cinnabarinus & A0A060SWE9 & 3.30 & 1 & 61.7 & 5.88 & Others \\
\hline Pycnoporus cinnabarinus & A0A060SUL2 & 3.21 & 1 & 35.2 & 4.75 & Glycoside hydrolases \\
\hline Pycnoporus cinnabarinus & A0A060SB04 & 3.20 & 1 & 81.4 & 5.03 & Hemicellulolytic enzymes \\
\hline Pycnoporus cinnabarinus & A0A060STT9 & 3.09 & 1 & 24.2 & 4.97 & Glycoside hydrolases \\
\hline Pycnoporus cinnabarinus & A0A060S4J1 & 2.98 & 1 & 49.3 & 5.94 & Lignin-degrading enzymes \\
\hline Pycnoporus cinnabarinus & A0A060SJV2 & 2.96 & 1 & 37.6 & 5.92 & Others \\
\hline Pycnoporus cinnabarinus & A0A060SPD3 & 2.93 & 1 & 41.8 & 4.93 & Glycoside hydrolases \\
\hline Pycnoporus cinnabarinus & A0A060SIS0 & 2.62 & 1 & 77.5 & 4.91 & Glycoside hydrolases \\
\hline Pycnoporus cinnabarinus & A0A060SRX7 & 2.54 & 1 & 62.0 & 5.91 & Glycoside hydrolases \\
\hline Pycnoporus sp. ZW02.30 & Q4TWI5 & 2.49 & 1 & 44.0 & 8.16 & Others \\
\hline Pycnoporus cinnabarinus & A0A060S411 & 2.36 & 1 & 67.5 & 8.90 & Glycoside hydrolases \\
\hline Pycnoporus cinnabarinus & A0A060SR05 & 2.34 & 1 & 77.1 & 5.52 & Cellulolytic enzymes \\
\hline Pycnoporus cinnabarinus & A0A060SBW4 & 2.22 & 1 & 15.4 & $\begin{array}{c}11.5 \\
2\end{array}$ & Others \\
\hline Pycnoporus cinnabarinus & A0A060SC99 & 2.20 & 1 & 45.3 & 5.06 & Glycoside hydrolases \\
\hline Pycnoporus cinnabarinus & A0A060SDL9 & 2.16 & 1 & 63.4 & 5.77 & Others \\
\hline Pycnoporus cinnabarinus & A0A060ST21 & 2.07 & 1 & 42.4 & 5.03 & Lignin-degrading enzymes \\
\hline Pycnoporus cinnabarinus & A0A060S8N7 & 2.04 & 1 & 120.2 & 5.19 & Glycoside hydrolases \\
\hline Pycnoporus cinnabarinus & A0A060S5J9 & 1.99 & 1 & 81.0 & 7.58 & Others \\
\hline Pycnoporus cinnabarinus & A0A060S404 & 1.96 & 1 & 21.1 & 8.60 & Glycoside hydrolases \\
\hline Pycnoporus cinnabarinus & A0A060SA81 & 1.95 & 1 & 51.4 & 6.21 & Glycoside hydrolases \\
\hline
\end{tabular}


bioRxiv preprint doi: https://doi org/10.1101/2020.09.22.308908; this version posted September 23, 2020. The copyright holder for this preprint (which was not certified by peer review) is the author/funder, who has granted bioRxiv a license to display the preprint in perpetuity. It is made available under aCC-BY-NC-ND 4.0 International license.

\begin{tabular}{|c|c|c|c|c|c|c|c|}
\hline Carboxylic ester hydrolase & Pycnoporus cinnabarinus & A0A060SBR5 & 1.93 & 1 & 59.5 & 4.86 & Others \\
\hline $\begin{array}{l}\text { Glucose oxidase (GMC } \\
\text { oxidoreductase) } *\end{array}$ & Pycnoporus cinnabarinus & A0A060SC37 & 1.90 & 1 & 65.6 & 5.58 & Lignin-degrading enzymes \\
\hline
\end{tabular}

Table 3. Detailed information of 56 characterized proteins from G. applanatum secretome. ${ }^{\text {a }}$ matched protein ID was derived from the G. lucidum genome database (Chen et al. 2012). ${ }^{\mathrm{b}}$ the sequences of matched peptides are shown in Table S3. ${ }^{*}$ indicates the presence of a signal peptide in the matched protein

\begin{tabular}{|c|c|c|c|c|c|c|c|}
\hline Protein name & Ortolog organism & Protein ID $^{\mathbf{a}}$ & Score & $\begin{array}{c}\text { Total } \mathbf{n}^{\circ} \\
\text { of } \\
\text { peptides } \\
\text { matches }^{b}\end{array}$ & $\mathbf{M W}$ & pI & $\begin{array}{l}\text { Functional } \\
\text { classification }\end{array}$ \\
\hline $\begin{array}{l}\text { Glycoside Hydrolase } \\
\text { Family } 3 \text { protein * }\end{array}$ & Laccaria bicolor & GL27550-R1_1 & 34.53 & 13 & 85.4 & 5.06 & Glycoside hydrolases \\
\hline Beta-galactosidase $\mathbf{C} *$ & Aspergillus niger & GL23290-R1_1 & 33.87 & 13 & 112.9 & 5.36 & Hemicellulolytic enzymes \\
\hline Copper radical oxidase & Phanerochaete chrysosporium & GL27858-R1_1 & 31.28 & 12 & 98.4 & 4.49 & Lignin-degrading enzymes \\
\hline Peptidase M28 * & Arthroderma otae & GL20779-R1_1 & 16.68 & 6 & 52.8 & 5.06 & Others \\
\hline Alpha-galactosidase * & Zygosaccharomyces cidri & GL30909-R1_1 & 14.91 & 5 & 47.4 & 5.55 & Hemicellulolytic enzymes \\
\hline Beta-xylosidase & Postia placenta & GL22886-R1_1 & 11.91 & 5 & 86.7 & 5.21 & Hemicellulolytic enzymes \\
\hline $\begin{array}{l}\text { Serine-type } \\
\text { carboxypeptidase } \mathbf{F} *\end{array}$ & Aspergillus niger & GL29240-R1_1 & 10.39 & 4 & 57.1 & 4.83 & Others \\
\hline $\begin{array}{l}\text { Glycoside Hydrolase } \\
\text { Family } 92 \text { protein * }\end{array}$ & Schizophyllum commune & GL23422-R1_1 & 10.39 & 4 & 93.1 & 5.24 & Glycoside hydrolases \\
\hline Laccase * & Pycnoporus cinnabarinus & GL16398-R1_1 & 10.38 & 3 & 56.6 & 4.87 & Lignin-degrading enzymes \\
\hline Beta-galactosidase A & Neosartorya fischeri & GL23225-R1_1 & 9.88 & 4 & 223.8 & 5.12 & Hemicellulolytic enzymes \\
\hline Laccase * & Pycnoporus cinnabarinus & GL29486-R1_1 & 8.29 & 3 & 56.2 & 6.04 & Lignin-degrading enzymes \\
\hline Amidase C869.01* & Schizosaccharomyces pombe & GL20521-R1_1 & 8.11 & 3 & 57.5 & 5.01 & Others \\
\hline Histone H4 & Phanerochaete chrysosporium & GL24962-R2_1 & 6.76 & 2 & 13.6 & 11.60 & Others \\
\hline $\begin{array}{l}\text { Mannose-6- } \\
\text { phosphatase * }\end{array}$ & Phanerochaete chrysosporium & GL20532-R1_1 & 5.42 & 2 & 37.7 & 5.11 & Others \\
\hline $\begin{array}{l}\text { Mannose-6- } \\
\text { phosphatase * }\end{array}$ & Phanerochaete chrysosporium & GL24763-R1_1 & 5.34 & 2 & 39.7 & 6.80 & Others \\
\hline Beta-galactosidase $\mathbf{C} *$ & Aspergillus niger & GL23249-R1_1 & 5.07 & 2 & 107.0 & 6.37 & Hemicellulolytic enzymes \\
\hline Beta-actin & Schizophyllum commune & GL26629-R1_1 & 4.46 & 2 & 41.5 & 5.68 & Others \\
\hline $\begin{array}{l}\text { Translation elongation } \\
\text { factor } 1 \text { alpha }\end{array}$ & Schizophyllum commune & GL29943-R1_1 & 4.45 & 2 & 119.4 & 8.53 & Others \\
\hline Lipase $1 *$ & Candida rugosa & GL16765-R1_1 & 4.32 & 2 & 58.4 & 4.75 & Others \\
\hline Beta-xylosidasa * & Postia placenta & GL19093-R1_1 & 4.31 & 2 & 87.5 & 5.21 & Hemicellulolytic enzymes \\
\hline Endopeptidase * & Coprinopsis cinerea & GL31420-R1_1 & 3.99 & 2 & 46.5 & 5.01 & Others \\
\hline $\begin{array}{l}\text { Alpha subunit } \\
\text { mitochondrial ATP } \\
\text { synthase }\end{array}$ & Neurospora crassa & GL18722-R1_1 & 3.97 & 2 & 61.7 & 9.06 & Others \\
\hline Laccase-2 * & Trametes villosa & GL29490-R1_1 & 3.68 & 1 & 54.4 & 4.93 & Lignin-degrading enzymes \\
\hline $\begin{array}{l}\mathrm{N} \text { - } \\
\text { acetylhexosaminidase * }\end{array}$ & Postia placenta & GL24346-R1_1 & 3.31 & 1 & 60.0 & 5.08 & Others \\
\hline $\begin{array}{l}\text { tRNA (adenine }(58) \text { - } \\
\text { N(1))- } \\
\text { methyltransferase non- } \\
\text { catalytic subunit TRM6 }\end{array}$ & Cryptococcus neoformans & GL30358-R1_1 & 3.21 & 2 & 54.5 & 6.15 & Others \\
\hline $\begin{array}{l}\text { glycoside hydrolase } \\
\text { family } 88 \text { protein * }\end{array}$ & Postia placenta & GL16281-R1_1 & 3.07 & 1 & 44.3 & 5.17 & Glycoside hydrolases \\
\hline Oxidoreductase * & Trametes coccinea & GL30723-R1_1 & 3.02 & 1 & 30.9 & 8.22 & Lignin-degrading enzymes \\
\hline $\begin{array}{l}\text { Glycoside Hydrolase } \\
\text { Family } 95 \text { protein * }\end{array}$ & Laccaria bicolor & GL21099-R1_1 & 2.83 & 1 & 90.2 & 5.10 & Glycoside hydrolases \\
\hline Peroxiredoxin & Dichomitus squalens & GL23044-R2_1 & 2.77 & 1 & 20.6 & 6.20 & Others \\
\hline $\begin{array}{l}\text { Heat shock protein } \\
\text { HSS1 }\end{array}$ & Puccinia graminis & GL24688-R1_1 & 2.72 & 1 & 66.7 & 5.30 & Others \\
\hline
\end{tabular}


bioRxiv preprint doi: https://doi.org/10.1101/2020.09.22.308908; this version posted September 23, 2020. The copyright holder for this preprint (which was not certified by peer review) is the author/funder, who has granted bioRxiv a license to display the preprint in perpetuity. It is made available under aCC-BY-NC-ND 4.0 International license.

\begin{tabular}{|c|c|c|c|c|c|c|c|}
\hline $\begin{array}{l}\text { Proteasome subunit } \\
\text { alpha type } 5\end{array}$ & Coprinopsis cinerea & GL30143-R1_1 & 2.71 & 1 & 29.2 & 5.73 & Others \\
\hline Transporter & Ganoderma sinense & GL20524-R1_1 & 2.65 & 1 & 43.8 & 5.40 & Others \\
\hline $\begin{array}{l}\text { Glycoside hydrolase } \\
\text { family } 47 \text { protein * }\end{array}$ & Dichomitus squalens & GL20698-R2_1 & 2.61 & 1 & 55.6 & 5.08 & Glycoside hydrolases \\
\hline $\begin{array}{l}\text { Nop52-domain- } \\
\text { containing protein } *\end{array}$ & Dichomitus squalens & GL29484-R1_1 & 2.58 & 1 & 39.6 & 7.97 & Others \\
\hline $\begin{array}{l}\text { Glycoside Hydrolase } \\
\text { Family } 92 \text { protein * }\end{array}$ & Schizophyllum commune & GL18249-R1_1 & 2.51 & 1 & 92.7 & 4.97 & Glycoside hydrolases \\
\hline $\begin{array}{l}\text { Probable glucano endo- } \\
\text { 1,6-beta-glucosidasa B } \\
*\end{array}$ & Aspergillus terreus & GL21683-R1_1 & 2.49 & 1 & 53.6 & 5.49 & Cellulolytic enzymes \\
\hline $\begin{array}{l}\text { Vegetative } \\
\text { incompatibility protein } \\
\text { HET-E-1 }\end{array}$ & Podospora anserina & GL28315-R1_1 & 2.38 & 1 & 63.2 & 5.54 & Others \\
\hline Cellobiohydrolase * & Polyporus arcularius & GL30351-R1_1 & 2.37 & 1 & 49.1 & 4.65 & Cellulolytic enzymes \\
\hline $\begin{array}{l}\text { Putative isomerase } \\
\text { YbhE }\end{array}$ & Dichomitus squalens & GL18873-R1_1 & 2.31 & 1 & 37.0 & 4.79 & Putative proteins \\
\hline $\begin{array}{l}\text { Glyceraldehyde-3- } \\
\text { phosphate } \\
\text { dehydrogenase }\end{array}$ & Ganoderma lucidum & GL21313-R1_1 & 2.25 & 1 & 34.3 & 6.39 & Others \\
\hline $\begin{array}{l}\text { ATP synthase F1 beta } \\
\text { subunit }\end{array}$ & Dichomitus squalens & GL24652-R1_1 & 2.24 & 1 & 57.9 & 5.78 & Others \\
\hline Alpha-glucosidase * & Dichomitus squalens & GL22859-R1_1 & 2.21 & 1 & 97.8 & 6.62 & Hemicellulolytic enzymes \\
\hline $\begin{array}{l}\text { Glycoside Hydrolase } \\
\text { Family } 15 *\end{array}$ & Laccaria bicolor & GL23580-R1_1 & 2.15 & 1 & 61.0 & 5.27 & Glycoside hydrolases \\
\hline $\begin{array}{l}\text { carbohydrate-binding } \\
\text { module family } 43 \\
\text { protein }\end{array}$ & Trametes coccinea & GL29873-R2_1 & 2.14 & 1 & 87.9 & 5.07 & Others \\
\hline $\begin{array}{l}\text { Aspartyl-tRNA } \\
\text { synthetase }\end{array}$ & Schizosaccharomyces pombe & GL21592-R1_1 & 2.11 & 1 & 58.5 & 6.77 & Others \\
\hline $\begin{array}{l}\text { Glycoside Hydrolase } \\
\text { Family } 74 \text { protein }\end{array}$ & Phanerochaete chrysosporium & GL30540-R1_1 & 2.09 & 1 & 76.2 & 4.93 & Glycoside hydrolases \\
\hline $\begin{array}{l}\text { Glycoside Hydrolase } \\
\text { Family } 18 \text { / } \\
\text { Carbohydrate-Binding } \\
\text { Module Family } 5 \\
\text { protein * }\end{array}$ & Trametes cinnabarina & GL22147-R1_1 & 2.08 & 1 & 49.4 & 5.36 & Glycoside hydrolases \\
\hline $\begin{array}{l}\text { Nufleófilo } \\
\text { Aminohidrolasa N- } \\
\text { terminal }\end{array}$ & Dichomitus squalens & GL25209-R1_1 & 2.03 & 1 & 33.4 & 7.55 & Others \\
\hline $\begin{array}{l}\text { Glycoside hydrolase } \\
\text { family } 28 \text { protein * }\end{array}$ & Trametes coccinea & GL22710-R1_1 & 2.02 & 1 & 46.3 & 4.53 & Glycoside hydrolases \\
\hline $\begin{array}{l}\text { Alpha-ketoacid } \\
\text { dehydrogenase kinase }\end{array}$ & Dichomitus squalens & GL17521-R1_1 & 2.00 & 1 & 51.5 & 7.36 & Others \\
\hline Transporter & Ganoderma sinense & GL19409-R1_1 & 1.97 & 1 & 219.2 & 5.40 & Others \\
\hline $\begin{array}{l}\text { N-acetyltransferase } \\
\text { eso1 }\end{array}$ & Schizosaccharomyces pombe & GL25858-R1_1 & 1.95 & 1 & 82.4 & 6.70 & Others \\
\hline $\begin{array}{l}\text { Glycoside Hydrolase } \\
\text { Family } 15 \text { proteim }\end{array}$ & Laccaria bicolor & GL23600-R1_1 & 1.95 & 1 & 57.3 & 4.45 & Glycoside hydrolases \\
\hline Histone H2A & Agaricus bisporus & GL22513-R1_1 & 1.93 & 1 & 14.6 & 10.08 & Others \\
\hline $\begin{array}{l}\text { Translation elongation } \\
\text { factor } \mathbf{T u}\end{array}$ & Schizosaccharomyces pombe & GL30320-R1_1 & 1.90 & 1 & 52.4 & 8.31 & Others \\
\hline $\begin{array}{l}\text { Voltage-gated } \\
\text { potassium channel }\end{array}$ & Dichomitus squalens & GL23555-R2_1 & 1.90 & 1 & 43.3 & 5.30 & Others \\
\hline
\end{tabular}




\section{Conclusions}

In this study, Pycnoporus sanguineus and Ganoderma applanatum secretomes were evaluated as pretreatment agents in a fermentable-sugar obtaining process. The inductive medium containing Panicum prionitis leaves increased the percentage of hydrolyzed cellulose compared with a non-inductive medium. The pretreatment efficiency and the activities of the main hydrolytic enzymes were higher using $P$. sanguineus secretome. Diverse proteins were identified and functionally classified according to their biological role. Many uncharacterized proteins were found, reflecting the still insufficient knowledge of the mechanisms underlying lignocellulose degradation. Interestingly, a putative glucose-tolerant $\beta$-glucosidase was identified in $P$. sanguineus secretome, opening new avenues for second-generation biofuel production. 


\section{Acknowledgements}

This work was supported by AGENCIA NACIONAL DE PROMOCION CIENTIFICA Y TECNOLOGICA (D-TEC 2013 N 0001/13) and SECTEI-Santa Fe Province (Res 156/2017). The funding source had no involvement in study design. Authors would like to thank their supporting organisms and institutions. AG is a fellow of Fundación Ciencias Agrarias. ASL is a fellow of Consejo Nacional de Investigaciones Científicas y Técnicas (CONICET). VEP is a Professor at Universidad Nacional de Rosario (UNR). SRF and HRP are Professors at Universidad Nacional de Rosario (UNR) and researchers of IICAR-CONICET. 


\section{REFERENCES}

1. Alfenore, S., Molina-Jouve, C., 2016. Current status and future prospects of conversion of lignocellulosic resources to biofuels using yeasts and bacteria. Process Biochem. 51, 1747-1756. DOI: 10.1016/j.procbio.2016.07.028

2. Behera, B.C., Sethi, B.K., Mishra, R.R., Dutta, S.K., Thatoi, H.N., 2017. Microbial cellulases-diversity \& biotechnology with reference to mangrove environment: A review. J. Genet. Eng. Biotechnol. 15, 197-210. DOI: 10.1016/j.jgeb.2016.12.001

3. Cairns, J.R.K., Esen, A., 2010. $\beta$-Glucosidases. Cell Mol. Life Sci. 67, 3389-3405. DOI: $10.1007 / \mathrm{s} 00018-010-0399-2$

4. Camarero, S., García, O., Vidal, T., Colom, J., del Río, J.C., Gutiérrez, A., Martínez, M.J., Martínez, A.T., 2002. Flax pulp bleaching and residual lignin modification by laccase-mediator systems, in: Viikari, L., Lantto, R. (Eds.), Biotechnology in the pulp and paper industry. Elsevier Science BV, Amsterdam, pp. 213-222.

5. Cantarel, B.I., Coutinho, P.M., Rancurel, C., Bernard, T., Lombard, V., Henrissat, B., 2009. The Carbohydrate-Active EnZymes database (CAZy): An expert resource for glycogenomics. Nucleic Acids Res. 37, D233-D238. DOI: 10.1093/nar/gkn663

6. Chandel, A.K., Gonçalves, B.C., Strap, J.L., da Silva, S.S., 2015. Biodelignification of lignocellulose substrates: An intrinsic and sustainable pretreatment strategy for clean energy production. Crit. Rev. Biotechnol. 35, 281-293. DOI: $10.3109 / 07388551.2013 .841638$

7. Cheah, W.Y., Sankaran, R., Show, P.L., Ibrahim, T.N.B.T., Chew, K.W., Culaba, A., Chang, J.S., 2020. Pretreatment methods for lignocellulosic biofuels production: current advances, challenges and future prospects. Biofuel Res. J. 7, 1115-1127. DOI:10.18331/BRJ2020.7.1.4 
8. Chen, S., Xu, J., Liu, C., Zhu, Y., Nelson, D.R., Zhou, S., et al., 2012. Genome sequence of the model medicinal mushroom Ganoderma lucidum. Nat. Commun. 3, 1-9. DOI: $10.1038 /$ ncomms192

9. Couturier, M., Berrin, J.G., 2013. The saccharification step: the main enzymatic components, in Faraco, V. (Ed.), Lignocellulose Conversion. Springer, Berlin, Heidelberg, pp. 93-110.

10. Dashtban, M., Schraft, H., Syed, T.A., Qin, W., 2010. Fungal biodegradation and enzymatic modification of lignin. Int. J. Biochem. Mol. Biol. 1, 36-50.

11. de Giuseppe, P.O., Souza, T.D.A., Souza, F.H.M., Zanphorlin, L.M., Machado, C.B., Ward, R.J., Jorge, J.A., Furriel, R.P.M., Murakami, M.T., 2014. Structural basis for glucose tolerance in GH1 $\beta$-glucosidases. Acta Crystallog. D Biol. Crystallog. 70, 1631-1639. DOI: 10.1107/S1399004714006920

12. Eugenio, M.E., Carbajo, J.M., Martín, J.A., González, A.E., Villar, J.C., 2009. Laccase production by Pycnoporus sanguineus under different culture conditions. J. Basic Microbiol. 49, 433-440. DOI: 10.1002/jobm.200800347

13. Gauna, A., Larran, A.S., Perotti, V.E., Feldman, S.R., Permingeat, H.R., 2018. Fungal pretreatments improve the efficiency of saccharification of Panicum prionitis Ness biomass. Biofuels 1-7. DOI: 10.1080/17597269.2018.1479934

14. Georis, J., Lomascolo, A., Camarero, S., Dorgeo, V., Herpoël, I., Asther, M., Martinez, A.T., Dauvrin, T., 2003. Pycnoporus cinnabarinus laccases: an interesting tool for food or non-food applications. Commun. Agric. Appl. Biol. Sci. 68, 263-266.

15. Glass, N.L., Schmoll, M., Cate, J.H., Coradetti, S., 2013. Plant cell wall deconstruction by ascomycete fungi. Annu. Rev. Microbiol. 67, 477-498. DOI: 10.1146/annurevmicro-092611-150044 
16. Guo, B., Amano, Y., Nozaki, K., 2016. Improvements in glucose sensitivity and stability of Trichoderma reesei $\beta$-glucosidase using site-directed mutagenesis. PloS one 11, e0147301. DOI: 10.1371/journal.pone.0147301

17. Guo, H., Wang, X.D., Lee, D.J., 2018. Proteomic researches for lignocellulosedegrading enzymes: A mini-review. Bioresour. Technol. 265, 532-541. DOI: 10.1016/j.biortech.2018.05.101

18. Habu, N., Samejima, M., Dean, J.F., Eriksson, K.E.L., 1993. Release of the FAD domain from cellobiose oxidase by proteases from cellulolytic cultures of Phanerochaete chrysosporium. FEBS Lett. 327, 161-164. DOI: 10.1016/00145793(93)80162-N

19. Huang, Y., Busk, P.K., Grell, M.N., Zhao, H., Lange, L., 2014. Identification of a $\beta$ glucosidase from the Mucor circinelloides genome by peptide pattern recognition. Enzyme Microb. Technol. 67, 47-52. DOI: 10.1016/j.enzmictec.2014.09.002

20. IPCC (Intergovernmental Panel on Climate Change, Climate Change) 2014 Mitigation of Climate Change, 2014. doi:10.1017/CBO9781107415416.

21. Jain, K.K., Kumar, A., Shankar, A., Pandey, D., Chaudhary, B., Sharma, K.K., 2020. De novo transcriptome assembly and protein profiling of copper-induced lignocellulolytic fungus Ganoderma lucidum MDU-7 reveals genes involved in lignocellulose degradation and terpenoid biosynthetic pathways. Genomics 112, 184198. DOI: $10.1016 /$ j.ygeno.2019.01.012

22. Jeya, M., Joo, A.R., Lee, K.M., Tiwari, M.K., Lee, K.M., Kim, S.H., Lee, J.K., 2010. Characterization of $\beta$-glucosidase from a strain of Penicillium purpurogenum KJS506. Appl. Microbiol. Biotechnol. 86, 1473-1484. DOI: 10.1007/s00253-009-2395-8 
23. Larran, A.S., Jozami, E., Vicario, L., Feldman, S.R., Podesta, F.E., Permingeat, H.R., 2015. Evaluation of biological pretreatments to increase the efficiency of the saccharification process using Spartina argentinensis as a biomass resource. Bioresour. Technol. 194, 320-325. DOI: 10.1016/j.biortech.2015.06.150

24. Limayem, A., Ricke, S.C., 2012. Lignocellulosic biomass for bioethanol production: current perspectives, potential issues and future prospects. Prog. Energy Combust. Sci. 38, 449-467. DOI: 10.1016/j.pecs.2012.03.002

25. Lu, C., Wang, H., Luo, Y., Guo, L., 2010. An efficient system for pre-delignification of gramineous biofuel feedstock in vitro: application of a laccase from Pycnoporus sanguineus H275. Process Biochem. 45, 1141-1147. DOI: 10.1016/j.procbio.2010.04.010

26. Manavalan, T., Manavalan, A., Heese, K., 2015. Characterization of lignocellulolytic enzymes from white-rot fungi. Curr. Microbiol. 70, 485-498. DOI: 10.1007/s00284014-0743-0

27. Manavalan, T., Manavalan, A., Thangavelu, K.P., Heese, K., 2012. Secretome analysis of Ganoderma lucidum cultivated in sugarcane bagasse. J. Proteom. 77, 298-309. DOI: 10.1016/j.jprot.2012.09.004

28. Mariano, D.C.B., Leite, C., Santos, L.H.S., Marins, L.F., Machado, K.S., Werhli, A.V., Lima, L.H.F., Melo-Minardi, R.C., 2017. Characterization of glucose-tolerant $\beta$-glucosidases used in biofuel production under the bioinformatics perspective: A systematic review. Genet. Mol. Res. 16, 1-19. DOI: 10.4238/gmr16039740

29. Masran, R., Zanirun, Z., Bahrin, E.K., Ibrahim, M.F., Yee, P.L., Abd-Aziz, S., 2016. Harnessing the potential of ligninolytic enzymes for lignocellulosic biomass 
pretreatment. Appl. Microbiol. Biotechnol. 100, 5231-5246. DOI: 10.1007/s00253016-7545-1

30. Medina, M.L., Kiernan, U.A., Francisco, W.A., 2004. Proteomic analysis of rutininduced secreted proteins from Aspergillus flavus. Fungal Genet. Biol. 41, 327-335. DOI: 10.1016/j.fgb.2003.11.014

31. Monteiro, L.M.O., Vici, A.C., Pinheiro, M.P., Heinen, P.R., Cavalcante de Oliveira, A.H., Ward, R.J., Prade, A., Buckeridge, M.S., Teixeira de Moraes Polizeli, M.L., 2020. A highly glucose tolerant B-glucosidase from Malbranchea pulchella (mp bg3) enables cellulose saccharification. Sci. Rep. 10, 1-12. DOI: 10.1038/s41598-02063972-y

32. Mood, S.H., Golfeshan, A.H., Tabatabaei, M., Jouzani, G.S., Najafi, G.H., Gholami, M., Ardjmand, M., 2013. Lignocellulosic biomass to bioethanol, a comprehensive review with a focus on pretreatment. Renew. Sust. Energ. Rev. 27, 77-93. DOI: 10.1016/j.rser.2013.06.033

33. Moukha, S.M., Dumonceaux, T.J., Record, E., Archibald, F.S., 1999. Cloning and analysis of Pycnoporus cinnabarinus cellobiose dehydrogenase. Gene 234, 23-33. DOI: 10.1016/S0378-1119(99)00189-4

34. Niderhaus, C., Garrido, M., Insani, M., Campos, E., Wirth, S., 2018. Heterologous production and characterization of a thermostable GH10 family endo-xylanase from Pycnoporus sanguineus BAFC 2126. Process Biochem. 67, 92-98. DOI: 10.1016/j.procbio.2018.01.017

35. Polizeli, M.L.T.M., Rizzatti, A.C.S., Monti, R., Terenzi, H.F., Jorge, J.A., Amorim, D.S., 2005. Xylanases from fungi: properties and industrial applications. Appl. Microbiol. Biotechnol. 67, 577-591. DOI: 10.1007/s00253-005-1904-7 
36. Robak, K., Balcerek, M., 2018. Review of second generation bioethanol production from residual biomass. Food Technol. Biotech. 56, 174-187. DOI: 10.17113/ftb.56.02.18.5428

37. Rohr, C.O., Levin, L.N., Mentaberry, A.N., Wirth, S.A., 2013. A first insight into Pycnoporus sanguineus BAFC 2126 transcriptome. PloS One 8, e81033. DOI: 10.1371/journal.pone.0081033

38. Salehi Jouzani, G., Taherzadeh, M.J., 2015. Advances in consolidated bioprocessing systems for bioethanol and butanol production from biomass: a comprehensive review. Biofuel Res. J. 2, 152-195. DOI: 10.18331/BRJ2015.2.1.4

39. Salgado, J.C.S., Meleiro, L.P., Carli, S., Ward, R.J., 2018. Glucose tolerant and glucose stimulated $\beta$-glucosidases-a review. Bioresour. Technol. 267, 704-713. DOI: 10.1016/j.biortech.2018.07.137

40. Santos, C.A., Morais, M.A.B., Terrett, O.M., Lyczakowski, J.L., Zanphorlin, L.M., Ferreira-Filho, J.A., Tonoli, C.C.C., Murakami, M.T., Dupree, P., Souza, A.P., 2019. An engineered GH1 $\beta$-glucosidase displays enhanced glucose tolerance and increased sugar release from lignocellulosic materials. Sci. Rep. 9, 1-10. DOI: 10.1038/s41598$019-41300-3$

41. Scarpa, J.D.C.P., Marques, N.P., Monteiro, D.A., Martins, J.M., Veloso de Paula, A., Boscolo, M., da Silva, R., Gomes, E., Bocchini, D.A., 2019. Saccharification of pretreated sugarcane bagasse using enzymes solution from Pycnoporus sanguineus MCA 16 and cellulosic ethanol production. Ind. Crop Prod. 141, 111795. DOI: 10.1016/j.indcrop.2019.111795

42. Shankar, A., Ahlawat, S., Sharma, K.K., 2019. Exploring fungi-associated lignocellulose degradation: secretomic and proteomic approaches, in: Satyanarayana, 
T., Deshmukh, S.K., Deshpande, M.V. (Eds.), Advancing frontiers in mycology \& mycotechnology. Springer, Singapore, pp. 251-277.

43. Siqueira, E.D.A., Mizuta, K., Giglio, J.R., 1997. Pycnoporus sanguineus: a novel source of $\alpha$-amylase. Mycol. Res. 101, 188-190. DOI: 10.1017/S0953756296002547

44. Smânia, A., Marques, C.J.S., Smânia, E.F.A., Zanetti, C.R., Carobrez, S.G., Tramonte, R., Loguercio-Leite, C., 2003. Toxicity and antiviral activity of cinnabarin obtained from Pycnoporus sanguineus (Fr.) Murr. Phytother. Res. 17, 1069-1072. DOI: 10.1002/ptr.1304

45. Sosa, L.L., Jozami, E., Oakley, L.J., Montero, G.A., Ferreras, L.A., Venturi, G., Feldman, S.R., 2019. Using C4 perennial rangeland grasses for bioenergy. Biomass Bioenerg. 128, 105299. DOI: 10.1016/j.biombioe.2019.105299

46. Suzuki, H., Igarashi, K., Samejima, M., 2008. Real-time quantitative analysis of carbon catabolite derepression of cellulolytic genes expressed in the basidiomycete Phanerochaete chrysosporium. Appl. Microbiol. Biotechnol. 80, 99-106. DOI: $10.1007 / \mathrm{s} 00253-008-1539-6$

47. Uzan, E., Nousiainen, P., Balland, V., Sipila, J., Piumi, F., Navarro, D., Asther, M., Record, E., Lomascolo, A., 2010. High redox potential laccases from the ligninolytic fungi Pycnoporus coccineus and Pycnoporus sanguineus suitable for white biotechnology: from gene cloning to enzyme characterization and applications. J. Appl. Microbiol. 108, 2199-2213. DOI: 10.1111/j.1365-2672.2009.04623.x

48. Valappil, P.K., Christopher, M., Sukumaran, R.K., Rajasree, K.P., Abraham, A., 2019. Characterization of a glucose tolerant b-glucosidase from Aspergillus unguis with high potential as a blend-in for biomass hydrolyzing enzyme cocktails. Biotechnol. Lett. 41, 1201-1211. DOI: 10.1007/s10529-019-02724-z 
49. Xiao, Z., Zhang, X., Gregg, D.J., Saddler, J.N., 2004. Effects of sugar inhibition on cellulases and $\beta$-glucosidase during enzymatic hydrolysis of softwood substrates, in: proceedings of the twenty-fifth symposium on biotechnology for fuels and chemicals Held May 4-7, 2003, in Breckenridge, CO. Humana Press, Totowa, NJ, pp. 11151126.

50. Yu, G.J., Yin, Y.L., Yu, W.H., Liu, W., Jin, Y.X., Shrestha, A., Yang, Q., Ye, X.D., Sun, H., 2015. Proteome exploration to provide a resource for the investigation of Ganoderma lucidum. PloS One 10, e0119439. DOI:10.1371/journal.pone.0119439

51. Zhou, X.W., Su, K.Q., Zhang, Y.M., 2012. Applied modern biotechnology for cultivation of Ganoderma and development of their products. Appl. Microbiol. Biotechnol. 93, 941-963. DOI: 10.1007/s00253-011-3780-7 